II 小児急性リンパ性白血病再発例を対象に

\title{
II-1. 末梢血幹細胞移植
}

小児PBSCT 研究会

渡辺新

小児 ALL に対する治療成績の向上は目覚ましく, この背景には, (1)初発時予後因子の解析の進歩, (2)化 学療法およびその支持療法の進歩, (3)各種造血幹細胞 救済療法の併用による治療選択肢の増加などがある が, 依然として極めて難治性の高リスク患者が存在す ることと, 再発後の予後は初発時の予後因子にかかわ らず極めて不良となることが問題点として残されてい る ${ }^{1)}$. 通常の化学療法をより強力に長期に行うことに よって治療成績は向上するが, 抗癌剤の総投与量の増 大に伴って心筋障害 ${ }^{2} \cdot$ 二次癌 ${ }^{3)}$ ・成長障害・生殖障害 などの晚期障害の増大は避けられず，また強力な維持 療法中の再発は腫瘍細胞の多剤而性化を意味し, その 後の治療は困難になってくることが多い. 表 1 に示し たように, 小児 ALL 再発例において, 初回寛解後比較 的早期に再発した症例（早期再発例）ではすでに薬剤 耐性化が進んでいると考えられ，通常の化学療法では 第 2 寛解維持は極めて困難であることが多い. 一方, 初回寛解を長く維持した後に再発した症例（晚期再発 例）の多くはすでに大量のアンスラサイクリン系抗癌 剤を投与されており，心毒性の発現を考慮するとさら に上乗せして使用することは重大な危険が伴うため,
表 1 小児再発 ALL に対する治療戦略

（1）初発から18力月末満で再発した早期再発例 問題点: 再寬解後, 通常の化学療法レジメンでは寬解維持 は困難。

$\longrightarrow \mathrm{DCV} \rightarrow \mathrm{HD}-\mathrm{AraC}$ 交代療法による 7 カ月の 強化療法後に MCVAC 療法を前処置として PBSCT を行う。

（2）初発から18カ月以上で再発した晩期再発例 問題点：すでに大量の抗ガン剤が投与されていること. $\longrightarrow$ Intensive L-asparaginase 療法による 7 カ月の 強化療法後に MCVAC 療法を前処置.として PBSCT を行い, 移植後 1 年間の維持療法を行う。

使用可能な抗癌剤は制限され第 2 寛解維持はやはり困 難となってくる. 初回寛解例において検討中の PBSCT の有用性, すなわち治療期間の短縮と抗癌剤 の総使用量の削減は, 再発後の小児 ALL 患児におい ても有用である可能性がある4).まず PBSCTをゴー ルとして集中した大量癌化学療法を行うことにより早 期再発例に見られる薬剤耐性を克服する可能性がある ことと, PBSCT をゴールとして治療期間を短縮する

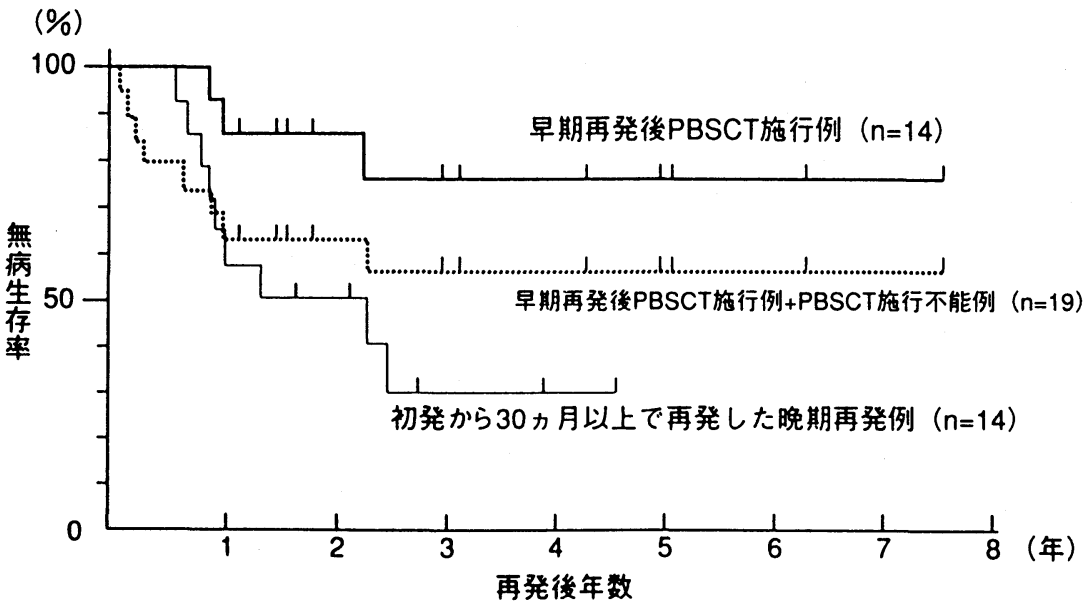

図 1 再発後 PBSCT を計面した小児 ALL 33例

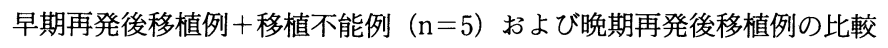




\section{早期再発例に対するプロトコール（Re g i m e n I ）}

$1^{1} 1^{2}+1^{4}, 5,6,1,1,1,10,11,12,13,14,15,16,17,16,11,20,21,22,23,26,25,26,21,21,29,30,31,32$

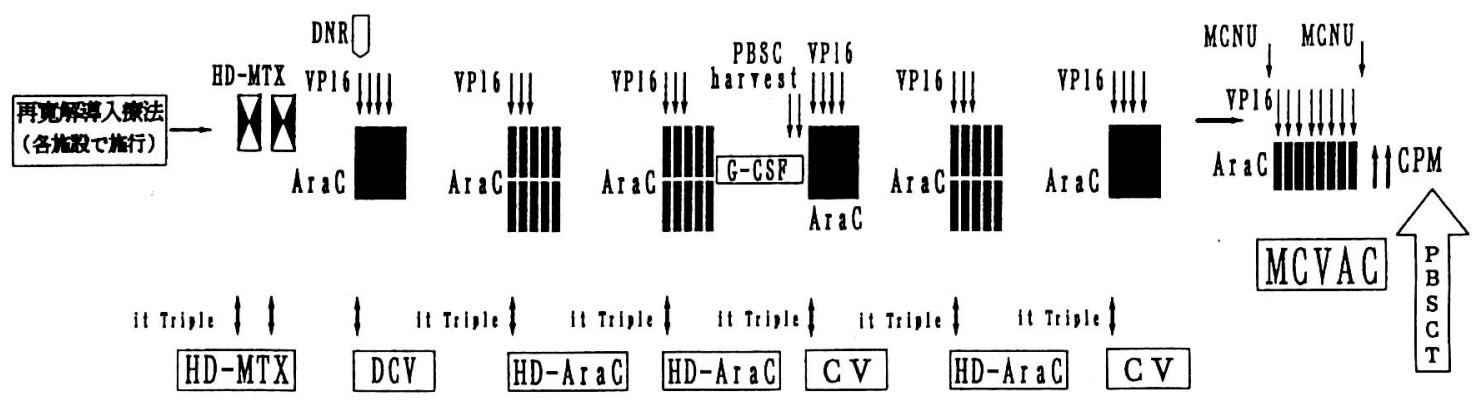

\section{晚期再発例に対するプロトコール（R e g i m e n II ）}
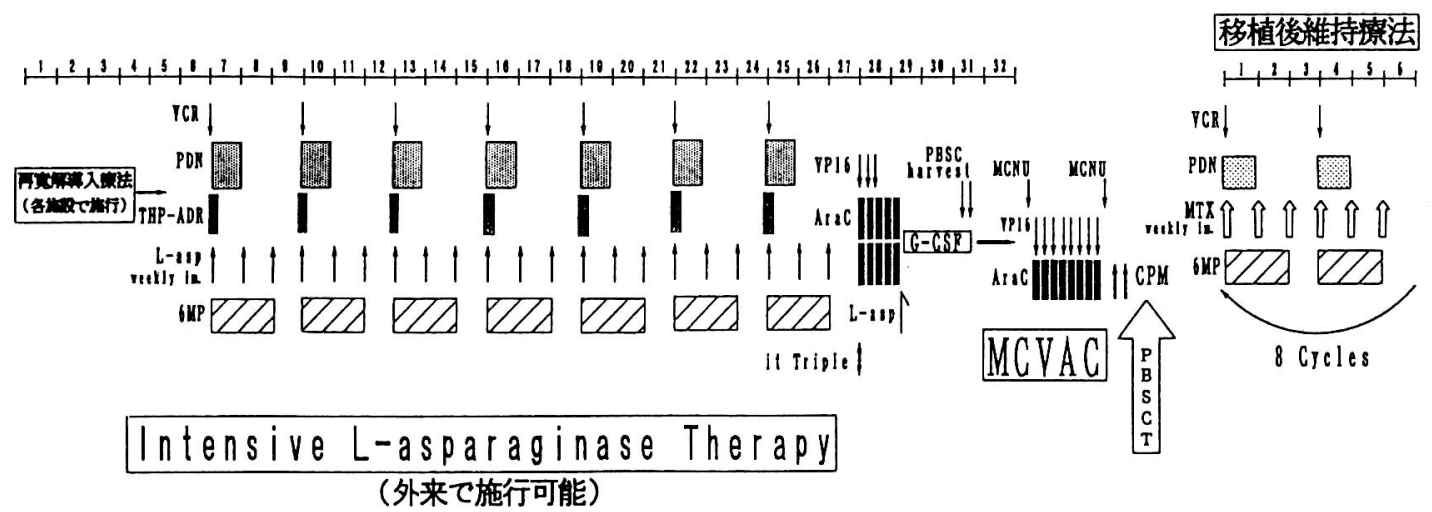

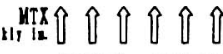

図 2 小児再発 ALL に対する治療プロトコール

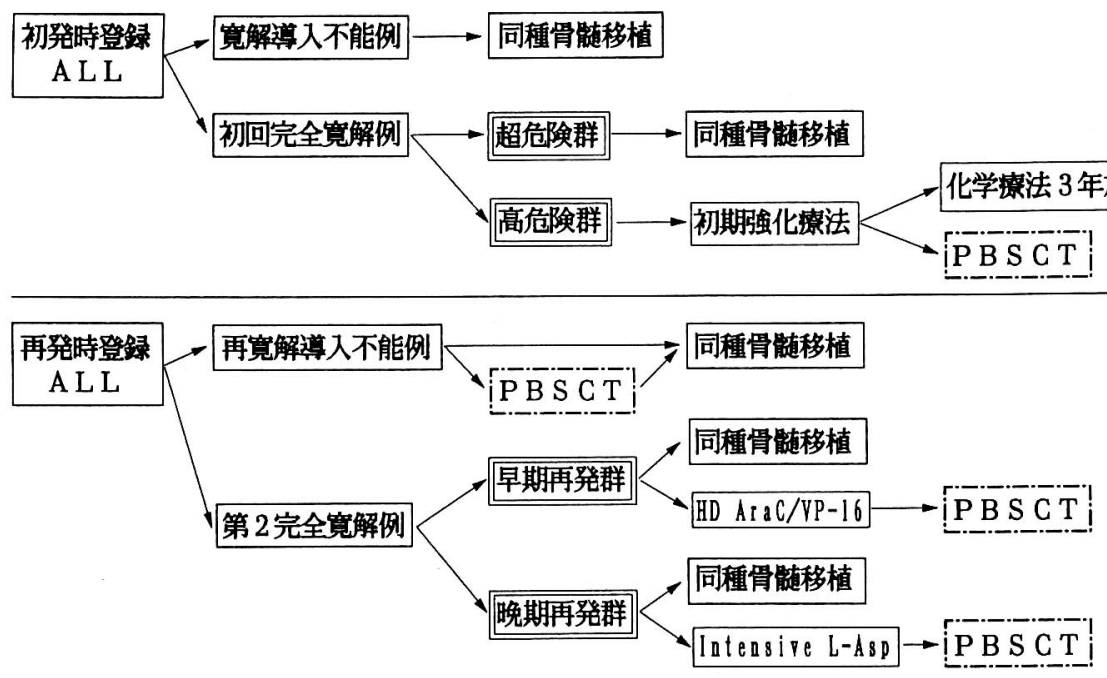

図 3 小児ALL 治療戦略におけるPBSCT の位置ずけ 
ことにより再発後の総抗癌剤使用量を大幅に削減し, 治療合併症を少なくして治癒後の患児の QOL を向上 させる可能性があることである.小児 PBSCT 研究会 で再発後に PBSCT を計画した小児 ALL 33例の治療 成績を図 1 に示す.第 2 寛解が得られて実際に PBSCT が行われた28例では, 通常極めて予後不良と される早期再発例（初発から18力月未満で再発したも の）14例中11例が移植後無治療で無病気生存中である のに対し, 早期再発例と比較した場合, 通常やや予後 良好とされる晚期再発例（初発から30力月以上で再発 したもの）14例中 9 例が PBSCT 後に再発しており, 通常の化学療法で得られる成績と全く逆の効果が得ら れている. 早期再発例の多くは, 第 2 寛解期に $\mathrm{AraC} /$ VP16を key drug として強化療法を間欠的にくり返 し受けており,この強化療法後に MCNUを key drug とした MCVAC 療法を前処置としたPBSCT を施行 したことが早期再発例に特に効果を現す可能性がある と考えられた. 図 2 に示すように現在小児PBSCT 研 究会では小児再発 ALL 症例に対し, 再発時に登録し 再寛解導入後, 早期再発例に対する AraC/VP16を key drug とした強化療法を 8 力月間施行した後 PBSCT を行う Regimen I と, 晚期再発例に対する L-ASP key drug とした強化療法を 8 カ月間施行し た後 PBSCT を行う Regimen II が進行中であるが, 早期再発例 5 例が図 1 に点線で示すようにPBSCT を施行できていない.これは 5 例中 4 例で第 2 完全寛 解が得られなかったこと，1例が PBSCT 直前に再再 発したことによる, 従って小児再発ALLにおける PBSCT の有用性は, 全再発例の再発時登録とその後 の治療経過の検討により明らかになるものと考えられ
る.また小児再発 ALL で再寛解導入困難例が増えて きており ${ }^{5}$ ，そのような症例で初回寛解期に回収・凍結 保存された PBSC が存在すれば再寛解導入のための PBSCT を行うことが可能となることから, 初回寛解 期に全例でPBSC 回収を行うことは有意義であると 考えられる.図 3 に小児ALLの治療戦略における PBSCT の位置づけを示す. 各治療選択肢の中で PBSCT の有用性を検討していくには初発時・再発時 登録後, 詳細な臨床経過の比較検討が重要である.

\section{References}

1) Pui, C.H. and Crist, W.M. : Biology and treatment of acute lymphoblastic leukemia. J. Pediatr., 124 : 491-503, 1994.

2) Lipshultz, S.E., et al.: Late cardiac effects of doxorubicin therapy for acute lymphoblastic leukemia in childhood. N. Engl. J. Med., 324 : 808-815, 1991.

3) Naomi, J., et al.: Secondary acute myelid leukemia in children with acute lymphoblastic leukemia treated with etoposide. J. Clin. Oncol., 11: 209-217, 1993.

4) Takaue, Y., et al.: High-dose chemotherapy and blood stem cell autograft for children with relapsed acute lymphoblastic leukemia : A pilot study of the Children's Cancer and Leukimia Study Group of Japan (CCLSG). Med.Pediatr. Oncol., 23: 20-25, 1994.

5) von der Weid, N., et al.: Treatment of relapsed acute lymphoblastic leukemia in childhood. III. Experiences with 54 first bone marrow, nine isolated testcular, and eight isolated central nervous system relapses observed 1985-1989. Med. Pediatr. Oncol., 22 : 361-369, 1994. 